\title{
The Moral Truth About Normative Constructivism
}

\author{
Stuart Toddington
}

\section{Introduction}

Ken Westphal is to be commended for his accomplished explanation of what we can safely assume is essentially encompassed by the broad sweep of political, legal and moral thought that now identifies itself as Normative Constructivism. Two things put us on the right path in this regard. One is Westphal's positive decision to make sensible and compelling suggestions to look for rapprochement and synthesis between, on the one hand, the resignation to noumenal limitations in Kant's transcendentalism and, on the other, Hegel's passion to overcome the alienation of thought and object ethically and scientifically. The other, either by careful design or diplomatic omission, is by promoting a more expansive notion of constructivism that avoids the unhelpful diversion of pitting the officially subscribed 'social contract' theorists (Hobbes, Rousseau, Kant), to those who unconvincingly opposed it (Hume) ${ }^{1}$ and those who articulated important objections to it (Hegel). ${ }^{2}$ Thus we arrive at a

${ }^{1}$ David Hume, "Of the Original Contract" Moral and Political Essays [1748] reproduced in Social Contract: Essays by Locke Hume Rousseau (Sir Ernest Barker [ Ed] Oxford University Press, Oxford, 1960) pp. 147-166. This undoubtedly important essay from Hume offers some invaluable insights into the collective wisdom of populations who have reconstituted themselves after war and usurpation throughout the entirety of history. Whilst it successfully refutes the idea of an actual original contract of government in any society, it simply supports, in my view, the central arguments of Hobbes vision of Leviathan. There is no doubt of course that any notion of a constitutionally legitimating social contract is a rational reconstruction to be imputed not discovered historically.

${ }^{2}$ See: T.M.Knox [ Trans] Hegel's Philosophy of Right (Oxford University Press, Oxford, 1967 ) First Part: 'Contract' $\$ 75$ pp. 58,59. Here, Hegel, in describing Kant's subsumption of the concept of marriage and the concept of contract says,

It is equally far from the truth to ground the nature of the state in the contractual relation, whether the state is supposed to be a contract of all with all, or of all with the monarch and the government. 
point where we might survey the anatomy of normative constructivism with some critical confidence.

The first thing we can say about this long-standing school of constitutional constructivism that stretches from Hobbes through the work of the notables mentioned above, particularly to to Rawls $^{3}$ and Habermas ${ }^{4}$ and between and beyond, ${ }^{5}$ is that these authors, wary of the determinate application of Natural Law, agnostic toward the idea of Objective Right or positively antithetical to it, seek to combine 'significant' elements of a philosophical anthropology with a theory of social order in the attempt to synthesise normative justifications for authoritative institutions. Although this general methodological aspiration is a necessary attribute for inclusion within the paradigm of Normative Constructivism (in the sense that we are accustomed to receive it contemporarily), it is not a sufficient account of the strategy. Presenting legitimacy as the upshot of an equation which in some way combines a philosophical anthropology with a model of social order has not been the exclusive preserve of the authors of liberal modernity. Plato's Republic and Aquinas's interpretations of

The intrusion of this contractual relation, and relationships concerning private property generally, into the relation between the individual and the state has been productive of the greatest confusion in both constitutional law and public life.

Hegel goes on, importantly:

$\ldots$ in ...[R]ecent times the rights of the monarch and the state have been regarded as the subjects of a contract and as grounded in contract, something embodying merely a common will and resulting from the arbitrariness of parties united into a state. [emphasis added].

${ }^{3}$ See, e.g., Rawls, John, "Kantian Constructivism in Moral Theory" The Journal of Philosophy Vol. 77, No.9,1980 pp. 515-572

${ }^{4}$ See, generally, Habermas, Jurgen, The Theory of Communicative Action Vol.1 (Heinemann, London 1981

${ }^{5}$ Notably in Ronald Dworkin's conception of 'Law as Integrity' in Law's Empire (Harvard University Press ,1987). 
Aristotle $^{6}$ are but two examples of, respectively, ancient and mediaeval attempts to manipulate the equation in question. It is worthwhile noting at this point that constitutionally neither of these influential contributions to the philosophy of the state and social order depend upon, or advocate, the equality of right or the centrality of the individual. The kind of Constructivism we see evolving from Hobbes to Hegel, however, rests eventually upon an equation which was produced by a Copernican revolution in moral and political thought. In what becomes literally an inversion of the mediaeval conception of the state and the individual, we see the replacement of a theocratic model of institutional stasis, fixed hierarchy and the legitimating axioms of Aquinian 'revealed ends ${ }^{7}$ by the pivotal primacy of subjective right over objective notions of The Good. Thus the philosophical anthropology that attends this revolution consists in a model of the individual infused with what Alan Brudner calls, 'the liberal confidence': This is a set of presuppositions about the 'final worth' or end-status of the individual from which, eventually, and in the context of association and the exigencies of our physical finitude, constitutional norms are to be extrapolated. Brudner describes the claims of the 'liberal confidence' as consisting of the following propositions: ${ }^{8}$

[...] that the individual agent possesses final worth (which I shall sometimes call end-status) so that there is no more fundamental end to which it may be unilaterally subordinated; that it does so on its own, that is, as a separate individual, distinct from (that is, not immersed in or obliterated by or subsumed under) other individuals as well as from the larger groups, society, or political association of which it is a member; and that and that the individual's worth is inviolable, which means that everyone is under a duty to respect it by forbearing from attempts to subdue the individual's agency to his own ends or to some supposed superior end such as tribe, nation, society or state. This set of propositions constitutes what I shall call the liberal confidence.

\footnotetext{
${ }^{6}$ See Plato The Republic [Benjamin Jowett Trans. 1871]. See also Thomas Aquinas Commentary on Aristotle's Politics. In Aquinas: Political Writings. (Trans. R.W. Dyson. Cambridge: Cambridge University Press. 2002)

7 On the transition from mediaeval to modern constitutional principles see Alan Brudner Constitutional Goods (Oxford, Oxford University Press, 2004) pp.52,53
}

${ }^{8}$ Alan Brudner Constitutional Goods (Oxford, Oxford University Press, 2004) p.13 
There is scope for disagreement about the amount of enthusiasm which the classical constructivists in question can be said to display for this manifesto: for example, Hobbes is a great Liberal thinker, although often portrayed as authoritarian in outlook. But, even in what are sometimes assumed to be Hobbes's most security-conscious moments, we discern the thesis that the raison d'etre of constructing principles of social order is not to preserve hierarchy per se, or to preserve life per se, but to make possible the individual's potential for pursuit of the Goods of civilised associational life. ${ }^{9}$ The individual pursuit of the Good is, of course, the central theme in the writings of the most influential $20^{\text {th }}$ and $21^{\text {st }}$ century liberal theorists even though the most influential emphasis has focussed on the 'lexical priority' of Right over objective assumptions about the value of ends in order to elevate the subjective prerogative of the individual as the 'author' of his or her particular and personal conception of the good. Predictably, in the comparatively recent history of the literature this most undialectical concentration on the unique isolation of the individual produced an equally unbalanced reaction in liberalism's defence of 'community'. Espousing 'the liberal confidence' requires a coherent commitment to what is implied by acknowledging the ultimate worth of the individual not simply in terms of liberty, nor even liberty and equality, but holistically in liberty, equality and community. Un-dialectical or perhaps 'un-dialogical' emphasis on one or another aspect of the concept of liberal right unleashes a destructive potential on the other dimensions of freedom. A failure to fashion a coherent synthesis in this regard produces the attritional pathology of 'atomism', and we can say right from the outset that Westphal is right to mark out Hegel's Constructivism as the approach that is most alert to this destructive tendency in the philosophy of liberalism. This tendency is most comprehensively analysed in Alan Brudner's Constituional Goods (2004) where, in support of a non-transcendental

\footnotetext{
${ }^{9}$ Hobbes etc
} 
methodology based on (Hegel's) notion of mutual recognition, he says of prevailing liberalism: ${ }^{10}$

[...] there are constitutional rights but no constitutional goods. That is, there are no human goods qualified to override fundamental rights and so none fit in that sense for constitutional status. A fundamental right, on this theory, can be limited only by another fundamental right so as to achieve the point of both, or by laws ensuring equality in the exercise of right. Furthermore, there is, for the prevailing theory, no ideal of human personality (as specified by a determinate scheme of fundamental ends) whose fostering and promotion by the public authority individuals have a right to demand and that would on that account qualify for constitutional status.

Methodologically, then, embracing a coherent version 'the liberal confidence' demands a flawless integrity in the approach to constructing a theory of institutions. This is to be expected, because a commitment to the individual's final worth is the greater part of a philosophical anthropology itself, and it should be obvious that this profound claim about the human condition must determine in large part the other side of the constructivist equation, namely, the institutional structure that serves as a model of legitimate social order consistent with that final worth.

Westphal's analysis of the power of Constructivism in general is plausible and often compelling, and so, as noted, is his argument that Hegel presents us with a superior synthesis of the strivings of individual freedom within the sphere of cultural, ethical and legal authority. Thus I do not wish to take issue with these general conclusions per se but I am of the view that there is a straighter and narrower (if less comfortable and, for some, less palatable ) path to the destination Westphal has in view. And with this in mind I intend to engage briefly and selectively with a couple of the strategies of argumentation deployed. I intend to touch upon some implications of the (normative) objectivist/ subjectivist distinctions drawn in Euthyphro and of Westphal's suggestion that it is possible to assimilate Hume's

\footnotetext{
${ }^{10}$ Alan Brudner Constitutional Goods (Oxford, Oxford University Press, 2004) p.21
} 
methodological views in overcoming moral realism in general by 'artificial means' in this regard, and in Hegelian terms in particular. These issues are to a large extent subsumed methodologically by what I have tried to suggest is a powerful and problematic dialectic of implications between, on the one hand, the concept of final worth, and on the other, the conception of social order. Whilst this dialectic might not be fatal to a conceptually agile and 'pragmatic' approach to developing a Constructivist project of synthesising justificatory grounds for constitutional norms, it might prove to be a challenge to the sensibilities of 'strong' Constructivists perturbed by too close an encounter with what Westphal refers to as "real', mind- independent moral facts'. The first indication of an aversion to such facts occurs in Westphal's resistance to an objectivist interpretation of the unrequited exchange in Euthyphro. Let us briefly refresh our recollections of this famous conversation.

\section{Euthyphro}

The meeting between Socrates and Euthyphro takes place in urgent circumstances with very little time available to the two protagonists to converse. Socrates, as defendant, and Euthyphro, as plaintiff, meet in the porch outside the court of Archon awaiting to be summoned to participate in their respective trial proceedings. Piety is no casual topic for either protagonist: Socrates stands charged by Meletus with Impiety, namely, by inventing new Gods through poetry and denying the existence of the old Gods through sophistry; Euthyphro, appears to lay a charge against his father - believing himself duty-bound to the follow the pious example of Zeus in prosecuting his own father for the same transgression. Socrates is alarmed to hear of Euthyphro's dramatic intentions, and even more alarmed when Euthyphro tells him that his own family have accused him of acting impiously himself for so doing. Euthyphro says: "That shows, Socrates, how little they know of the opinions of the Gods about piety and impiety ... " Eventually and predictably, Socrates enquires, ”And what 
is piety, and what is impiety?". It is Euthyphro's seemingly reasonable response to this question that produces one of philosophy's most famous rejoinders. Euthyphro announces confidently that he is beyond criticism for his actions because he is merely following in the footsteps of Zeus whom men regard "... as the best and most righteous of the Gods". Euthyphro goes on to point out that it was Zeus who bound his father, Cronos, for devouring his sons and that moreover, Cronos too behaved similarly in respect of his father, Uranus. Euthyphro thus concludes:

And yet when I proceed against my father, they [Euthyphro's family] are angry with me. This is their inconsistent way of talking when the gods are concerned, and when I am concerned." [emphasis added]

From this point the logical fate of Euthyphro's misplaced confidence in Zeus as a reliable paragon is well known. It comes about in two pivotal stages for the purposes of the discussion in hand (although there is protracted argument in the actual dialogue). The first is the failure to grasp on the one hand, the relationship between contingent actions assumed to be instances of piety and, on the other, the ground of general maxims of piety. The second, and most important, arises when Euthyphro accepts that constant warring and disagreement amongst the Gods makes it difficult for us to look to them as consistent paragons of pious behaviour, but, at Socrates suggestion, accepts what we might refer to as the 'consensualist' amendment that, "what all the gods love is pious, what all the gods hate is impious". To this Socrates invites Eutyhyphro to consider whether piety is loved by the Gods because it is holy, or whether it is holy because it is loved by the gods. This logic of the inquiry is to mark the distinction between on the one hand a contingent 'accident' or attribute -of piety (i.e., the condition of being beloved of the Gods), and on the other, the 'essence' or necessarily inherent characteristic of piety (i.e., a possible reason that might explain why it is beloved by the Gods). This is straightforwardly relevant to our concerns and so let us for a moment move unceremoniously from the revered dialogue to a more convenient idiom. 
The Euthyphro is left famously incomplete and no conclusions on these issues are definitively advanced. But, as is often the case, understanding the questions can be more important than being presented with the answers. In contemplating the import of this notorious question Westphal sees what he takes to be an unnecessary opposition between objectivist and subjectivist accounts of moral normativity arising from Socrates' dissatisfaction with Euthyphro's 'consensualist' amendment. We are being forced to take sides on whether there is a fundamental, objective reality underpinning the various instances of what we perceive as the Good, or whether judgements of what is to be regarded as Good are merely the product of a pluralistic, personal (subjective) attitudes. Westphal suggests that even if the latter position is true we need not despair of constructing an objectively defensible theory of normativity for the political sciences.

He says: ${ }^{11}$

If moral distinctions depend upon attitudes ... then this augers conventionalism, relativism or scepticism ... [H] owever, such conclusions follow only with an additional premise I shall call the 'Arbitrariness Thesis'

This thesis maintains that: ${ }^{12}$

If moral standards are altogether artificial, then they are also relative, conventional or arbitrary and so are not objectively valid.

This latter, says Westphal, is false, and its rejection provides the key to Hume's Theory of Justice' , He quotes Hume thus:

Though the rules of justice be artificial, they are not arbitrary. Nor is the expression improper to call them Laws of Nature; if by natural we understand what is common to any species, or even if we confine it to mean what is inseparable from the species. (Treatise 3.2.1.19)

Let us briefly the rhetoric and argument of the dialogue and then retur to Hume.

${ }^{11}$ Ken Westphal "Hegel, Natural Law and Moral Constructivism” The Owl of Minerva (Vol pp.) 
To act piously, we can say, is to act morally; in other words it is to strive do our moral duty. Some interesting questions arise at this point: acting dutifully in this sense requires that we are aware of our obligations - to the state, to our families, to our friends and to the wider community. We can speak about acting morally, piously, justly, ethically and this variety of terms no doubt help us mark some interesting distinctions, but in general we can say that the morally dutiful person does not seek simply to satisfy his or her own interests and appetites, but must take into account the interests of others when he or she acts. Just who these others might be, and what interests in particular should concern us give us a hint of the complexity of the question. But if we aspire be good and to do good, we must ask ourselves the condensed version 'of this question: What is The Good?' This is the question on which the would-be 'pious' of the dialogue, or those interested in the nature of 'normative critique' should reflect. To learn how to do good we can observe and replicate the behaviour of others (like Zeus) who are assumed to be morally accomplished persons. But this is a mechanical exercise of mimicry and without understanding the essential principles of morality we can only hope that our circumstances mirror those of our paragons. The critical deficit here is obvious - we are condemned to practise virtue by rote, not, as Kant and Hegel might suggest, to give autonomous and reflective expression to our own moral freedom. The contingent circumstances in which a pious (moral or ethical) person is adjudged to act dutifully presupposes knowledge of principles underpinning general maxims which provide the critical purchase on these normative matters.

What the Euthyphro seeks to express is that in a community where our most revered paragons of normativity disagree continually and violently about what is right and wrong, permissible and impermissible, worthy and unworthy, we can learn nothing of the nature of such 
principles. Optimistically we might say that these squabbles among the paragons are in themselves irrelevant: on the profound subject of virtue and moral duty we will find consensus among them. But in examining this consensus (and this tack is reminiscent of Hume as we might presently note $)^{13}$ might we discern the essence of piety? Just as with Socrates' objection to Euthyphro's observing and replicating the single instance of Zeus's punishment of his father, we do not glean self- evidently the general underlying maxim of the action. Similarly, we might list all the objects of divine consensus and remain equally undedified. This is a returns us to square one. The traditionalist might suggest, optimistically, that with a larger sample of persons in agreement we might at least be on firmer ground with a larger reference group to emulate in our moral strivings. But the philosopher would say what Plato has Socrates say to Euthyphro: that we are no nearer to gleaning the essence of piety (or The Good, or the basis of Moral Right) because in our complacency about the moral authenticity of the paragons we choose - or are instructed - to revere, and of the power of consensus among them, we do not know (or perhaps have not even thought about) whether The Good is beloved of the paragons because it is good, or whether it is good because it is beloved of the paragons.

The inquiry in the dialogue, as noted, is unrequited. Euthyphro's intellectual performance is less than scintillating, and irritatingly, Socrates is content to appear humble and puzzled by the issues at hand. It seems that there is little prospect of metaphysical enlightenment for the reader. But we know enough about Plato's Idealism and the Theory of Forms to be certain that the relativist (pluralist or subjectivist) option seemingly on offer in the defining question put to Euthyphro is purely rhetorical, and that we should interpret the dialogue as an attempt to

${ }^{13}$ Hume does offer some thoughts on how we might approach scientific analysis of morality, but these are based on the thesis that linguistic references to the good and the moral are to be found among all races the nations, and that-significantly-some common element underpins this ubiquity of linguistic usage. 
hammer home the point that, in relation to the aspiration to piety or, we might say, to moral duty, action-guiding knowledge demands a general principle.

Moreover, given the determined line of questioning Socrates imposes on his hapless acquaintance, we have a pretty good idea what the essence of piety - the perfect form of The Good in relation to moral duty - would look like. In Enlightenment terminology it takes the form of a supreme moral principle - an imperative - and a necessarily categorical one; for it must arise from metaphysical knowledge of ends that are truly good in themselves. It is odd, therefore, that Westphal employs this particular dialogue in proposing a systematic approach to normative constructivism. For it demands that we give literal credence to the rhetoric of moral subjectivism as somehow providing the methodological insight that sets us on the right path towards an understanding of Constructivist analysis in social and political philosophy.

\section{Hume}

Might it not be wiser to draw the conclusion that Socrates' inquiries to Euthyphro should provoke us to think harder about locating a criterion for the Good (or the pious) rather than precipitously abandoning moral objectivity or moral realism and sprinting, theoretically, in the direction of what looks to be a fruitful constructivism. Because we should remember that replacing the words 'artificial' or 'conventional', with 'constructive' does very little philosophical work. In this regard we might also note that following up the lesson of Euthyphro with Hume's optimism about turning 'artificial' rules into 'natural laws' or 'laws of nature' is might prove to be problematic; not least because Hume's views about objective moral truths are straightforwardly (and, in the history of philosophy, famously and definitively) non-cognitivist. 
Hume's non-cognitivism is not inspired by Socrates' irrepressible interrogation of Euthyphro's superstitious confidence in the infallibility of an unlikely hypothetical consensus among warring, vindictive and jealous gods, but by a superbly focused continuation of Bacon's critique of the problem of induction and the logic of observation. As proponents of Constructivism, although anxious about the ontological commitments required by moral realism and keen to make the best of convention and artifice, we surely would not want to now end up in the same position as Hume in the Treatise notwithstanding Euthyphro. Hume is not 'neutral' or 'agnostic' about objective moral realism, he is decidedly sceptical. It is Hume who is responsible for a much more onerous distinction than moral realism/nonrealism, namely, the fact-value distinction (Hume's Fork) which underpins the Hume's famous 'Law' laying down the prohibition on purporting to derive a morally normatively 'ought' from an empirically grounded 'is'.

It is worth noting that Hume's critique of a science of values has by far outperformed its fragile foundations. Hume tells us that reason deals with a twofold division: relations of ideas and the relations between matters of fact and existence. Fact and existence are what we are able to observe to be contingently the case by use of our physical senses, whereas relations of ideas - or conceptual relations - present themselves to our understanding in terms of necessity or contradiction. This in itself is reasonable and plausible, and on the face of it there is no reason why we should exercise ourselves in mounting a challenge to it. However, we are being asked to accept that only propositions concerning matters of fact and existence convey any meaningful and genuinely informative knowledge, whereas the realm of the a priorihowever complex its appearance - is reduced simply to empty tautology. This doctrine, of course, was exhumed 200 years after Hume by the logical positivists and resulted in some of the most extreme and nihilistic conceptions of moral reasoning yet to be produced. ${ }^{14}$ There is

\footnotetext{
${ }^{14}$ See Stuart Toddington “ Dialectical Necessity and the Is-Ought Problem” in Gewirthian Perspectives on Human Rights - (Per Bauhn[ Ed.], Routledge, London, 2016) pp.63-78
} 
scope for detailed debate in these matters, but suffice it to say that even if the 'fact-value distinction' alluded to in Hume's Fork might be 'Constructively' re-stated, ${ }^{15}$ the problem of producing genuinely justifiable normative propositions from empirically descriptive observations appears to be insurmountable. ${ }^{16}$ So in moving from Plato to the rejection of 'the thesis of arbitrariness', and on to Hume's optimism about naturalising the artificial, we are making little progress in laying down a non-arbitrary basis for Constructivism.

\section{Constructivism and Moral Relevance}

Westphal is aware of this looming impasse because he suggests that we might take constructivist steps respectively to (1), find, (2), identify and sort basic and significant elements, within a 'domain of enquiry' (and here of course we must refer to a domain of

${ }^{15}$ Ibid.p.74 . On the matter of the sceptical or relativist 'Fork' and quoting Hume inter alia, I noted:

In the Enquiries of 1748, moral reasoning is not only juxtaposed to 'matters of fact and existence', in that we are to accept that "All reasonings may be divided into two kinds, namely, demonstrative reasoning, or that concerning relations of ideas and moral reasoning, or that concerning matters of fact and existence.", but we are also told [by Hume] that there is merely a difference in degree between mathematical and moral concepts. In the Philosophy of Morals of 1751, however, Hume announces, "Men are now cured of their passion for hypotheses and systems... and will hearken to no arguments but those which are derived from experience.". Men will, of course, still endeavour to " $[\ldots]$ find those universal principles from which all censure or approbation is ultimately derived ... but this is a question of fact, not of abstract science.". We have, then the 'Fork', but are now unsure upon which prong to skewer moral concepts.

${ }^{16}$ Ibid. See esp pp.68,69. The best attempt to overcome it of which I am aware is in Gewirth's Reason and Morality (Chicago University Press, Chicago, 1978 ) but this claims to derive a 'moral ought' not from an empirical 'is', but from a 'dialectically necessary' ought of practical reason. 
constitutional morality) (3)'construct adequate principles or adequate theory' for that domain' by (4) using 'preferred' principles of construction. ${ }^{17}$

Because (ex hypothesi the domain in question) these 'basic and significant elements must turn out to be 'subjective', we still face 'fundamental' problems because:

[...] historically and geographically (regionally, culturally) these various kinds of subjective basic elements vary significantly. Consequently they are undermined by the Pyrronhian ${ }^{18}$ dilemma $^{19}$ of the criterion (Westphal 2014 a 2016 )

We are thus "in dire need of": ${ }^{20}$

[... ] sufficiently robust moral principles to avoid or surmount those kinds of differences, which have their equally problematic counterparts if instead we try to base our moral principles or theory on claims about real mind independent moral facts.

How might we break the bonds of this compounding impasse? Westphal says,

The required objectivity can be identified and justified by a moral constructivism based instead upon objective basic elements (Step 1), namely: objective facts concerning our very finite species of embodied semi-rational agency, together with basic, pervasive features of our context of action, namely the globe we inhabit. The relevant facts concern basic human capacity to act so as to affect anything, together with our various all too human susceptibilities, e.g., the error, injury, deception, extortion or seduction.

One must agree at least with this list of ingredients for any possible notion - Constructivist or otherwise - of a political and ethical philosophy of human association and institutional norms. Immediately following this enumeration of the basic elements Westphal notes, importantly:

These are features of our conditio humane; they are morally relevant facts, but are not themselves moral facts. ${ }^{21}$

\footnotetext{
17 Westphall Ibid.
}

18 Ibid.

19

${ }^{20}$ Westphal

${ }^{21}$ Westpahal 
We can thus rapidly build and refine a model of constructivism from here. But we can also rapidly run into problems that might lead us to scrutinise more carefully the quote immediately above in which we are introduced to the important distinction between 'the morally relevant' and the 'morally factual'.. The methodological direction that suggests itself from this point is.one of mapping out the problems of social coordination that arise from the model of the human condition described above. Westphal recalls Hobbes's insights in this regard concerning unlimited freedom of human action: where there is uncertainty about what belongs to whom we can expect a system of inevitable mutual interference that undermines the possibility of effective action by anyone, especially where there is a need to coordinate the use of material resources including air, space, water and foodstuffs. ${ }^{22}$ Hobbes, Hume and Rousseau, says Westphal,

"[ ...] all recognise these problems of coordination as moral problems which can only be solved by public mutually recognised principles of action, together with their institutionalisation as social practices."

'Morality', 'moral relevance' and 'moral facts' will require some careful scrutiny from here on in, but in the sense in which morality refers to 'other-regarding' duties it makes sense to understand the institutionalization of social coordination practices as requiring regular and repeated forbearance on the part of individuals in respect of their relations with others. Where this forbearance is made obligatory, these co-ordinatory principles and practices begin to constitute what we can understand as the basis of law and civil society. Westphal reminds us that Rousseau's addition to Hobbes and Hume's basic observations articulate the fundamental ethical constitutional issue: ${ }^{23}$

\footnotetext{
${ }^{22}$ Westphal

${ }^{23}$ Here Westphal quotes Rousseau in the CS 4.8.30 1964
} 
[ ...] these fundamental social principles and practices can only be justified is legitimate, if and insofar as they provide for or secure the independence of each and all by ensuring that no one can attain or wield the kind of extent of power or wealth by which s/he can unilaterally command the decision and action of anyone else.

This outline of constructivist methodology and of the basic problems of constitutional legitimacy is uncontentious. Our introductory remarks concerning the normative issues implicated in producing an equation which combined a model of human nature (a philosophical anthropology) with a model of social order do however, come more sharply into critical focus. With this brief nod to egalitarianism we introduce, among other things, rights to security, freedom of decision and action, notions of power, and the recognition that the accumulation of property affects the security of freedom of action. In light of this, we must be more cautious about assuming that we can uncontentiously separate what is 'morally relevant' to what now must be claimed to be 'morally factual'.

\section{Constructivism and Moral Facts}

The reason why we should stand firm in response to the notorious question posed in Euthypro is that we are likely to produce obfuscation if we suggest that it is possible to establish constitutional foundations on the moral pluralism and subjectivism that flows from what we might call the 'consensualist' option. The scope for confusion in talking imprecisely about what is morally relevant and what is morally factual is considerable.

To avoid it we should begin by acknowledging that the account of normative constructivism Westphal plausibly perceives as having evolved from Hobbes to Hegel is a liberal normative constructivism, and rests upon an explicit commitment to the egalitarianism model of the final worth of the individual. This model, which, following Brudner, we referedr to as a statement of the 'liberal confidence', is a collection of straightforwardly metaphysical and moral claims about the intrinsic worth of the individual and the reciprocal rights and duties which accrue to 
the individual in respect of this intrinsic worth. Epistemologically it forms the core of our understanding of a rational and legitimate social order fit for free beings. To subscribe to it philosophically is to claim with justification that it expresses our most foundational understanding of what is necessarily true about the moral nature of the individual and hence about what ought to be true of individuals in association. In other words this is what is to be understood as moral fact. In this sense what is morally factual is easily and distinctly separable from what is contingently, yet crucially, relevant in moral terms about the condition of our existence as vulnerable, empirical beings dependent upon not only access to natural resources but also considerable amounts of social cooperation. And whilst the organisation of these exigencies might take many forms, and whilst these many forms or folkways might be normatively routinized into more or less effective and functional forms of social order, surely the aspiration of Normative Constructivism must seek to introduce the specificity of the moral facts of the 'liberal confidence' into the critical institutional design of social order. In Hegelian terms this achievement would be regarded as the historical emergence of the Objectification of Spirit. My point is that I cannot understand this as an artificial intrusion into economic and social relations, but rather as the morally rational announcing itself as the historically real. 